\title{
Fear of a Black planet: Climate apocalypse, Anthropocene futures and Black social thought
}

(C) The Author(s) 2021

Article reuse guidelines: sagepub.com/journals-permissions DOI: I0.1 I77/I36843I02II067980 journals.sagepub.com/home/est

@SAGE

\author{
Joe P. L. Davidson
}

University of Cambridge, Cambridge, UK

\section{Filipe Carreira da Silva}

Institute of Social Sciences, University of Lisbon, Portugal; Selwyn College, University of Cambridge, Cambridge, UK

\begin{abstract}
In recent years, images of climate catastrophe have become commonplace. However, Black visions of the confluence of the Anthropocene and the apocalypse have been largely ignored. As we argue in this article, Black social thought offers crucial resources for drawing out the implicit exclusions of dominant representations of climate breakdown and developing an alternative account of the planet's future. By reading a range of critical race theorists, from Frederick Douglass and W. E. B. Du Bois to Octavia Butler and Ta-Nehisi Coates, we propose a rethinking of the climate apocalypse. The African American theoretical and cultural tradition elaborates an image of the end of the world that emphasises the non-revelatory nature of climate catastrophe, warns against associating collapse with rebirth, and articulates a mode of maroon survivalism in which the apocalypse is an event to be endured and escaped rather than fatalistically expected or infinitely delayed.
\end{abstract}

\section{Keywords}

Anthropocene, apocalypse, Blackness, marronage, plantation slavery

\section{Corresponding author:}

Joe P. L. Davidson, Department of Sociology, University of Cambridge, Cambridge CB2 ISB, UK.

Email: jpld2@cam.ac.uk 
In the last decade, the cloud of climate apocalypse has settled on the cultural consciousness. Bleak visions of a future world of wild weather, scorched earth and flooded cities are becoming increasingly widespread. One only needs to look at the titles of some recent popular non-fiction books on climate futures to get a sense of the contemporary pessimism. Whether it be Bill McKibben's Falter: Has the Human Game Begun to Play Itself Out? (2019) or David Wallace-Wells's The Uninhabitable Earth (2019), the future appears to offer, at best, a brutal struggle for survival and, at worst, the possibility of human extinction. Now, in one sense, this is nothing new. The environmental movement, from George R. Stewart's (1941) pioneering ecological novel on the perfect storm and Rachel Carson's (1962) vision of a silent spring, has long been enlivened by a keen sense of the catastrophes on the horizon (Cassegård \& Thörn, 2018; McNeish, 2017). However, the emergence of Anthropocene discourse in the last decade has granted apocalyptic narratives renewed charge. In an important sense, as Déborah Danowski and Eduardo Viveiros de Castro (2016, p. 22) declare, the 'Anthropocene is the Apocalypse'. It marks the end of one world, the relative climatic stability of the Holocene era, and the beginning of a new one, where old expectations and narratives are rendered obsolete (Simon, 2020). In Bruno Latour's (2018, p. 17; emphasis in original) words, with the 'earthquake' of the Anthropocene, 'another ground, another earth, another soil has begun to stir, to quake, to be moved'.

As this comment suggests, social theorists are not immune to the apocalyptic mood on the climate crisis. To give a few examples, John Urry $(2011$, p. 36) calls for an 'epochalist' sociology attuned to climate-induced societal breakdown, Anna Tsing (2015, p. 21) wryly suggests that 'there might not be a collective happy ending', and John Bellamy Foster (2020, p. 35) warns that humanity is facing 'planetary ecological collapse'. These thinkers, for all their differences, gesture towards a twenty-first-century future stalked by the spectre of collapse, where the movement of the ground beneath our feet lays waste to the social world. However, it would be wrong to say that such apocalyptic narratives are accepted without question. While few social theorists doubt the seriousness of the climate crisis, many have voiced criticisms of understanding it in terms of the end of the world. For instance, there is a fear that the production of images of a ruined planet induces what Andreas Malm (2021, pp. 140-141) calls 'climate fatalism', an 'antipolitical' position that declares that action to avert the climate apocalypse is pointless (see also Swyngedouw, 2010).

Another criticism, more pertinent to the themes of this article, is that the apocalyptic framing of climate futures reproduces and reinforces racist and colonial assumptions. This claim builds on a broader desire to 'socialize the Anthropocene' or to demonstrate that the environmental crisis is the fruit not of the undifferentiated figure of the human but instead unequal relations of capital, power and knowledge (Clark \& Szerszynski, 2021, p. 49). Responding to previous adaptations of the Anthropocene, most prominently the Capitalocene (Moore, 2015), that highlight the role of capitalism in producing the looming climate catastrophe, a number of terms have been proposed, including the racial Capitalocene (Vergès, 2017), the white supremacy scene (Mirzoeff, 2018) and the Plantationocene (Davis et al., 2019), that ground its emergence in the relations of colonial domination and racist violence that have enveloped the globe since 1492. While these accounts primarily focus on the historical causes of the Anthropocene, notions of racial 
capitalism, white supremacy and the plantation system are also relevant to its apocalyptic consequences. For instance, there is a false universalism to recent apocalyptic discourse. In declaring that the end of the world is the fate of everybody everywhere, the fact that the climate crisis is having, and will have, its most serious consequences in the Global South is elided (Mitchell \& Chaudhury, 2020). Furthermore, the climate apocalypse serves as a cipher 'for deep-seated anxieties of racialized Others "taking over" the planet' (Gergen et al., 2020, p. 93). Whether this be accounts that foreground the environmental dangers of high birth rates in the Global South or images of climate refugees breaching the boundaries of the Global North, racially oppressed peoples are positioned as the forces of collapse.

At first glance, apocalyptic narratives seem to offer little in terms of thinking the Anthropocene in anti-racist terms. However, as we demonstrate here, this conclusion is premature. There are good reasons for thinking that the apocalypse offers a fecund framework for developing critical social theory in the face of climate catastrophe. Visions of apocalyptic futures have long been a means by which subaltern groups have conceptualised the world. From the millenarian peasant movements of early modern Europe to the rise of Rastafarianism in the postcolonial Caribbean, accounts of the end of the world critique the injustice of actually existing society and posit an emancipated society in the future. More specifically, when thinking about the relationship between the apocalypse, the Anthropocene and critical social theory, there are compelling reasons to focus on the African American theoretical and cultural tradition. The place of apocalyptic narratives in African American thought is well known. Images of the end of the world inflect the theology developed in the times of slavery (Baker, 1990), the work of writers like Toni Morrison and James Baldwin (Montgomery, 1996) and the music of Tupac and Public Enemy (Ford, 2018). Furthermore, scholars like Kimberly Smith (2007), Dianne Glave (2010) and Kimberly Ruffin (2010) have recuperated neglected environmental tendencies in the African American tradition, drawing out the way in which the experience of racial violence has fostered a distinctive understanding of ecological questions. So, Black social thought offers a promising resource for thinking the apocalypse and the Anthropocene together in anti-racist terms. However, the apocalyptic imaginaries and environmental concepts of Black thinkers are seldom considered comparatively. Given this, what happens when Black apocalypse and Black environmentalism are brought together? How does the confluence of these two elements change the narratives of the end of the world circulating in contemporary culture?

In response to these questions, this article argues that African American thinkers have reinvented climate apocalypse in three ways. The first section examines the revelatory function of apocalyptic narratives or the idea that they disclose something fundamental about the social world. By reading Antebellum slave narratives that focus on the entwinement of racial violence and environmental destruction in the post-apocalyptic landscapes of the American South, we trace how the experience of chattel slavery subverts and reforms the capacity of images of collapse to reveal the hidden truth of contemporary society. The second section turns to the association between the end of the world and 
accounts of radical social transformation. We focus on W. E. B. Du Bois's short story 'The Comet', which both exemplifies and questions the millenarian undercurrent of apocalyptic narratives. Du Bois, by subtly interweaving the past experience of slavery into a future tale of a destroyed planet, suggests that even the end of the world may not spell the end of the plantation system. In other words, the apocalypse, in and of itself, has little transformative power; it will not bring rebirth or renewal. Finally, the third section posits the apocalypse not as an event to be endlessly deferred or fatalistically expected but instead endured and escaped. By bringing together the modes of existence developed in maroon communities of fugitive slaves with Octavia Butler's account of a droughtstricken California in the near future, we suggest that the cycle of catastrophes is to be weathered until such a time that it can be blasted open. In the conclusion, we reflect on the metaphorical form of utopianism associated with contemporary climate marronage; escape can be evoked but not concretely imagined.

Before moving to this argument, a few preliminary points should be made. For the purposes of this article, the African American theoretical and cultural tradition refers to texts produced by enslaved peoples and their descendants that address the effects of the Middle Passage and its aftermath. Following Cornel West (2003, p. 11), we can thus define Black social thought as 'the interpretation of Afro-American history, highlighting the cultural heritage and political struggles, which provides desirable norms that should regulate responses to particular challenges presently confronting Afro-Americans'. So, when talking about Black environmentalism, we mean accounts of ecological destruction that foreground its relationship to the continuum of events beginning with the Middle Passage and chattel slavery and running through to Jim Crow segregation and mass incarceration. In a similar fashion, Black apocalypse refers to visions in which mass devastation and societal breakdown are grounded in this sequence of racialised oppression.

Two caveats should be added to this definition of Black social thought. First, a great diversity of forms is examined in this article, including slave narratives, post-apocalyptic fiction, hip hop and Afrofuturist film. Prima facie, these modes of expression may appear at some distance from the traditional forms of social theory (the essay, the article, the monograph and so on). However, as indicated by West's reference to cultural heritage, it would be wrong to exclude, in an a priori fashion, certain forms of Black expression from the field of social theory. In Barbara Christian's (1987, p. 52) words, Black 'theorizing [...] is often in narrative forms, in the stories we create, in riddles and proverbs, in the play with language, since dynamic rather than fixed ideas seem more to our liking'. To do justice to the dynamism of Black thought, the expansive approach adopted by this article is required. Second, Black social thought is not monolithic or insular. Instead, as Patricia Hill Collins (2002, p. 21) comments of Black feminism, it 'encompasses diverse and often contradictory meanings'. As we highlight, there are internal differences in the Black theoretical and cultural tradition, such that the meaning of the climate apocalypse for a heterosexual Black man like Du Bois betrays forms of heteronormativity and patriarchy. Furthermore, there are kinships between Black environmentalism and the ecological thinking developed by other oppressed groups, something highlighted by our mention of Maroon-Amerindian formations in the conclusion. 


\section{Plantation wastelands}

In the eighteenth and nineteenth centuries, the plantation system of the American South faced increasingly serious environmental crises. The export-driven commodity production of the Southern plantation, one node in a network of global capitalism, relied on the exploitation of slave labour and the intense cultivation of monocrops, such as tobacco and cotton (Woods, 1998). The rift in 'the metabolic interaction between man and the earth' that Karl Marx ([1867] 1976, p. 637) witnessed in nineteenth-century England, where capitalistic agriculture resulted in the degradation of previously fertile farmland (see Foster, 2020), and that Amílcar Cabral (1988) pursued with his agronomy of liberation in Western Africa in the 1950s (see César, 2018), also occurred in the American South. For example, over the course of the eighteenth and early nineteenth centuries, the previously rich lands of Virginia and Maryland were systematically depleted by tobacco, a crop notorious for its mineral-draining power (Kulikoff, 2001). In more southerly states, the cultivation of cotton had a similar effect, the ruthless exploitation of the land pushing the South to 'the brink of an ecological - and thus an economic - crisis' by the beginning of the Civil War (Maudlin, 2018, p. 12).

The economics of chattel slavery and settler colonialism, a seemingly endless supply of stolen labour from Africa and stolen land from Indigenous peoples, meant that there was very little incentive for planters to maintain the soil. The planters were not 'landlords but "laborlords", a 'geographically rootless' class who exhausted one piece of the earth before moving their enslaved workers to fresh land (Wright, 1986, p. 18). To borrow Saidiya Hartman's (2007) term, one of the afterlives of slavery was a landscape littered with the ghosts of the plantation. The planters, in sapping one piece of land and then moving onto the next, produced a world punctuated by abandoned buildings, empty fields and eroded soil. As Françoise Vergès (2017, p. 73) notes more generally, the Southern system of agriculture established a close connection 'between the Western conception of nature as "cheap" and the global organization of a "cheap", racialized, disposable workforce', the two bound together in the footloose disposition of the planters. For enslaved peoples, the unsustainable nature of this double disposability was clear. While masters and overseers 'strolled along the borders of the fields', the slave labourers 'turned the soils, tended the plants, and harvested the crops' and, in this way, 'acquired a firsthand knowledge of the cultivated landscape on the plantation' (Stewart, 2006, p. 11). To use Kathryn Yusoff's (2018, p. ii) words, the 'proximity of black and brown bodies' to the soil produced a 'forced intimacy with the inhuman'. As a consequence, a sense of kinship with the abused world of nonhuman nature was fostered in African American culture. Such solidarity can be seen in the sustainable agriculture practices developed on small garden plots (Carney, 2021) and the affection for farmyard animals voiced in some slave narratives and testimonies (Bennett, 2020).

The African American attentiveness to the travails of the natural world translated into a concern for the ecological wreckages left by slavery, something that is particularly evident in slave narratives of the Antebellum period. For example, in the opening passage of Frederick Douglass's My Bondage and My Freedom (1855), he reflects on the wasteland of his childhood home in Talbot County, Maryland. Douglass (1855, p. 33) reports that the region is 'remarkable for nothing' except the 'worn-out, sandy, desert- 
like appearance of its soil, the general dilapidation of its farms and fences, the indigent and spiritless character of its inhabitants, and the prevalence of ague and fever'. The coming together of environmental degradation, architectural dilapidation and human deprivation produces an image of a post-apocalyptic wasteland, a world where some great force has swept through greedily sapping all energy. The unsustainability of the plantation system is revealed in Douglass's narrative, the process of ravenously stripping the world of resources, both human and nonhuman, steadily pushing the planter class over an ecological cliff edge (Ellis, 2014).

Charles Ball's slave narrative Slavery in the United States (1837) reiterates Douglass's image of a wasted planet denuded of life (Davis et al., 2019). Ball (1837, pp. 47-48) describes Virginia and Maryland as lands that had once been 'fertile and productive' but, after generations of being exploited by tobacco planters, were now in a state of 'desolation and poverty'. Abandoned by the former planters, who had taken their enslaved labourers to new pastures, Ball $(1837$, p. 51$)$ witnessed a world defined by absence, desolation and death:

This destructive crop [tobacco] ruins the best land in a short time; [ ... ] the traveller will see large old family mansions of weather-beaten and neglected appearance, standing in the middle of vast fields of many hundred acres, the fences of which have rotted away.

The 'folly and wickedness of slavery' is written into the landscape of the American South; the 'aguish and sufferings' of the slave system are evident from the topographical ruins it has produced (Ball, 1837, p. 49). Ball paints a picture of a shattered world, in which the plantation system steadily devours itself, each new crop cycle undermining the basis on which the wealth and splendour of the masters was built.

These slave narratives, once read from the vantage point of the metabolic interaction between human beings and the earth, contain a warning. The post-apocalyptic wastelands produced by the plantation system offer a foretaste of the carbon-induced climate apocalypse of the contemporary moment. The fact that the logic underpinning the plantation system has an affinity with the one that propels contemporary climate devastation becomes clear in the work of Ta-Nehisi Coates. At the end of Between the World and Me (2015), a letter to his son, Coates draws out how the instrumentalism of plantation slavery, a key component in the emergence of the capitalist world system, has become a global force. Whereas slavery was 'caged by technology and by the limits of horsepower and wind', it helped lay the groundwork for 'the damming of seas for voltage, the extraction of coal, the transmuting of oil into food' (Coates, 2015, p. 150). The destructive ecological logics of the contemporary world cannot be reduced to those developed on the plantation, but the latter is one lens through which the consequences of the former can be approached and comprehended. For Coates (2015, pp. 150-151), in a world where '[p]lunder has matured into habit and addiction', where stolen labour and stolen land undergird an entire social order, it is no surprise that the wastelands of slavery are coming to haunt the globe as a whole: 'Something more fierce than Marcus Garvey is riding on the whirlwind. Something more awful than all our African ancestors is rising with the seas'. In other words, the broken bodies and ruined topographies of the past find 
an echo in the catastrophes on the horizon; the plantation system continues to ravage the earth, albeit in a ghostly, hidden fashion.

In one sense, Coates's invocation of plantation wastelands as a figure to understand the climate catastrophe takes up one of the key functions of apocalyptic narratives: revelation. The word apocalypse is derived from the Greek term for unveiling and disclosing (apokálypsis), with part of the function of apocalyptic visions to draw out 'aspects of the human condition' previously hidden behind a 'protective screen' (Hall, 2009 , p. 3). The revelatory function of the apocalypse becomes particularly significant in the context of the climate crisis. Ecologically destructive everyday practices - meat consumption, the ownership of private cars, frequent air travel and so on - have become normalised in the Global North, but their consequences are masked (Browne, 2018). While climate denialism has been largely discredited, this does not mean that the effects of these practices are transparent. In Ulrich Brand and Markus Wissen's (2021, p. 5) words, an environmentally unsustainable mode of life has successfully hidden 'the destruction in which it is rooted' through the 'externalization of material, social and ecological costs'. This externalisation process takes place both geographically, with the most toxic forms of industry and violent modes of extraction located in the Global South, and temporally, with actions in the present having their most destructive effects in the future. Visions of post-apocalyptic plantations draw out the inner destructiveness of the dominant tendencies of the contemporary moment, using an image from the past to highlight that ecological consequences cannot be forever externalised. Accounts of a world ravaged by the twin disposability of human and nonhuman nature illuminate the telos of the current social order. The planet's climate system is about 'to punish us with all the ferocity we have fed it', the latent ecological violence of racial capitalism on the cusp of breaking out into the open (Wallace-Wells, 2019, p. 211).

To some degree, the slave narratives of the nineteenth century fulfil the revelatory function of climate apocalypse. The ultimate truth of our world has already been witnessed on the desolate and abandoned farmlands of Virginia and Maryland. Yet, there is a note of scepticism in these African American accounts about revelation. Coates's neoslave narrative The Water Dancer (2019), which focuses on a failing tobacco plantation in the nineteenth century, is interesting in this context. The neoslave narrative, a genre that revives and reworks the Antebellum slave narrative, emerged in the 1980s in the aftermath of the disappointment of the Civil Rights movement as a means of grappling with the continuities in the African American experience (Rushdy, 1999). Continuing this tradition, The Water Dancer reflects on how, despite the profound changes between the nineteenth and twenty-first centuries, plantation wastelands retain a hold in the time of climate catastrophe. On the one hand, the forced intimacy with the land means that, for enslaved people and their ancestors, there is nothing secret or hidden about the destructiveness of the plantation system. African American labourers 'knew what the land whispered, because none lived closer to the land than those who worked it' (Coates, 2019, p. 236). On the other hand, the revelations of the climate apocalypse have failed to break the central illusion of the plantation system: that labour and land can be exploited without consequence. The planter class, and white society more generally, are 'lost in dreams', unable to imagine a mode of life in which the metabolic interaction between humanity and the earth is reconstituted on a new basis (Coates, 2019, p. 653). 
From the perspective of white supremacy and racial capitalism, the apocalypse is an impossibility, such that the post-apocalyptic landscapes of the plantation fail to pique a sense of recognition or concern.

The scepticism about the revelatory function of apocalypse stems from the peculiar temporality of Black apocalyptic narratives. In N. K. Jemisin's words, it is 'the apocalypse again and again and again', each new wave of racial violence and environmental destruction reprising and replaying the catastrophic coming together of cheap nature and cheap labour in the plantation system (Hurley \& Jemisin, 2018, p. 472). The recursive, cyclical nature of the apocalypse means that, for African Americans, the end of the world has given everything that it has to give and any hope that images of ecologically devastated landscapes will inspire a transformation in white consciousness has long been extinguished. Those who failed to be moved by images of vanquished plantations in the past will not be pushed to action by visions of the catastrophes on the horizon. The impending climate catastrophe does not represent a fundamentally novel scenario. Instead, the apocalypse on the horizon in the twenty-first century recalls and recharges the rifts that have enveloped the planet since the Middle Passage. The revelatory power of the apocalypse is exhausted, each new return to catastrophe confirming the impotence of the figure of the end of the world.

\section{Apocalypse without transformation}

Martin Delany, an African American writer famous for his novel Blake; or the Huts of America (1859), had an interest in extraterrestrial objects, with his journalism exploring contemporary scientific research on the cosmos (Rusert, 2013). In an article titled 'Comets', Delany ([1859] 2003, pp. 313-314) emphasises the vital power of comets in the universe:

The purpose of comets would seem to be to distribute electricity throughout universal space, re-supplying the continual loss that must be sustained to systems and planets by various causes, and thereby giving life, action, health and vigor to both animate and inanimate creation, to this and distant worlds, worlds to us unknown.

In this passage, Delany offers a subtle commentary on plantation slavery. The desire for an alien body that can recharge worlds, restoring them to a state of plenty, stands in decisive contrast to the wastelands described by Douglass and Ball. If slavery has exhausted both labour and land, then comets promise to rejuvenate them.

Delany's glance upwards speaks to Nigel Clark and Bronislaw Szerszynski's (2021, p. 78) notion of 'planetary multiplicity', demonstrating an ability to 'reflect on the expanding alphabet and grammar of celestial bodies'. That the Earth is contingent on its interactions with other bodies in the cosmos is also taken up in another reflection on extraterrestrial objects in the African American tradition: Du Bois's short story 'The Comet', which was first published in Darkwater (1920). Like Delany, Du Bois posits comets as agents of change, granting them the power to both destroy and transform the world. Du Bois's story focuses on the consequences of the arrival of a comet in New York. The gasses of the comet have a catastrophic impact on the city, almost all of its 
inhabitants are killed by the shift in the atmospheric conditions. However, a workingclass Black man named Jim and a rich white woman named Julia survive the comet's impact. The couple, with the aid of the arrival of the celestial object, begin a new world based on equality and recognition. For Julia, Jim is no longer 'a thing apart' but 'her Brother Humanity incarnate', while Jim feels the 'shackles' of the old world 'fall from his soul' (Du Bois, 1920, pp. 269-270). The hopefulness of 'The Comet' is ambiguous. As Alexis Lothian (2018, p. 126) stresses, the image of a sexual union between a Black man and a white woman recreating the world invokes 'a heteronormative future of postracial, eugenic humanity'; utopian beginnings are entangled with gender inequality and compulsory heterosexuality. At the same time, the apocalypse becomes an agent of atmospheric and social transformation, the othering of Earth's meteorology laying the groundwork for a limited, constrained form of Black liberation.

Du Bois's story is the fruit of a long engagement with nonhuman nature in his work (Smith, 2007). The entwinement of white supremacy and the environment is particularly clear in 'Of Beauty and Death', which precedes 'The Comet' in Darkwater (Claborn, 2014; Oliver, 2015). In this essay, Du Bois (1920, p. 231) contrasts the ugliness of segregation in America and the beauty of nonhuman nature:

There is not in the world a more disgraceful denial of human brotherhood than the 'JimCrow' car of the southern United States; but, too, just as true, there is nothing more beautiful in the universe than sunset and moonlight on Montego Bay in far Jamaica. And both things are true and both belong to this our world, and neither can be denied.

On the one hand, the beauty and power of Montego Bay promises the possibility of a world of harmony and freedom, offering a decisive contrast to the prevailing racist social order. Just as the arrival of the comet transfigures New York, the splendour of the natural world transforms the Jim Crow section of the train carriage. On the other hand, the image of Montego Bay is haunted by the experience of racial violence. As Du Bois (1920, p. 230) reports elsewhere in the essay, many Black Americans 'don't travel much' - failing to witness the wilderness first-hand - because such trips would involve entering the Jim Crow car (see Foster, 1999). There is no way to escape from racism without going through it, such that the image of the nonhuman natural world is tainted and marked, both physically (through the destructiveness of plantation slavery) and aesthetically (through consciousness of the ugliness of the social world), by the continuum of events beginning with the Middle Passage.

The fraught relationship between nature and society is reflected in 'The Comet'. The arrival of the comet upturns the Earth, with Du Bois presenting us with an image of Jim and Julia on the cusp of creating a new social order. However, just as Montego Bay is accompanied by the spectre of Jim Crow, the comet cannot entirely shake its association with white supremacy. It transpires that the world has only ended in New York and the rest of the United States is untouched by the atmospheric changes triggered by the comet. At the end of the story, Julia's father emerges in a motorcar, accuses Jim of sexual assault, and breaks up the couple. With this intervention, the gaze between Jim and Julia 'faltered and fell'; the new Earth inaugurated by the comet is swallowed up by the return of the racist structures of the old world (Du Bois, 1920, p. 270). The utopian edge of Du 
Bois's story, in which the end of the world is a precursor to liberation, is undercut by the pessimism of the close of 'The Comet'. Even the kinship of the desire for equality and the energy-giving forces of an alien object is insufficient to extinguish slavery and segregation. The latter retain a ghostly hold on Du Bois's atmospheric apocalypse, the forces of racism managing to first resist and then dominate the new climatic conditions.

Du Bois's suspicion of the association between apocalypse and renewal is grounded in African American history. Apocalyptic narratives have a key place in the religious consciousness of African Americans, providing one of the vectors of hope retrieved from a critical reading of the Bible. As Houston Baker (1990, p. 56) notes, for enslaved Black people, the apocalypse offered the possibility of 'the conflagration of a slave-holding society and [...] their subsequent emergence from servitude'. Civil War and Reconstruction were interpreted in such apocalyptic terms, the abolition of slavery understood as marking 'the end of one age and the beginning of another' (Harper, 2016, p. 9). The apocalypse, by the time Du Bois was writing, was part of the African American experience, it was not simply something futural but had a correspondence with concrete events in history. Not only had the apocalypse already happened, one world ended and another begun, but it had also been disappointed. Reconstruction did not bring the millennium. The rollback of the reforms won in the aftermath of the Civil War and the rise of the Jim Crow system in the South made the last quarter of the nineteenth century a moment of pain, defeat and oppression, resulting in the feeling that apocalypse had failed to deliver.

With this dialectic of hope and disappointment, Du Bois questions the transformative potential of apocalyptic narratives. As Northrop Frye (1982, pp. 135-136) suggests, in the Christian tradition, the apocalypse is double sided, telling a story of 'portentous events in both social and natural orders: plagues, wars, famines, great stars falling from heaven, and an eventual transformation [...] of the world into a new heaven and earth'. The idea that the apocalypse has the potential to transform the world for the better has a latent presence in discourses on the Anthropocene (Skrimshire, 2019). Roy Scranton (2015, p. 22), in his otherwise bleak Learning to Die in the Anthropocene, hints at the rejuvenating power of climate collapse: 'For humanity to survive in the Anthropocene, we need to learn to live with and through the end of our current civilization'. Rupert Read, a philosopher associated with Extinction Rebellion, makes this point even more explicitly, suggesting that when 'this civilisation' - based on endless growth and fossilfuel consumption - inevitably breaks down, it may 'seed something radically different from itself from within its dying body’ (Read \& Alexander, 2019, p. 5; emphasis in original). On this perspective, apocalyptic narratives involve 'regressive redemption', where the collapse of the contemporary order does not spell the end of human sociality as such and, instead, offers a blank slate on which a different mode of living can be established (Colebrook, 2012, p. 204).

However, from Du Bois's perspective, the association between apocalypse and rebirth fails to convince. Any claims to racial progress, rooted as they are in the Enlightenment teleology of progress, are hopelessly unrealistic (Seamster \& Ray, 2018). The travails of the African American experience, where even the apocalypse of the Civil War failed to dismantle the twin forces of cheap nature and cheap labour, means that the hope that accompanies the end of the world - whether that be from the deadly gasses of a comet or 
the wrath of Gaia - jostles against disappointment. In a subterranean fashion, 'The Comet' anticipates Geoff Mann and Joel Wainwright's (2018, p. 11) warning that: 'The coming crisis is not "unmanageable"; it is already here, already being managed by liberal capitalism (if rather badly)'. In the face of the apocalypse, old tendencies are reformed; they confront climatic challenges, turn them to their own advantage and reformulate racial capitalism for a new age. The experience of facing the apocalypse again and again means that the impotence of the end of the world stretches beyond its revelatory function. It is not only the case that images of catastrophe fail to disclose anything hidden but they also lack the force to impel a transformation of the social order, representing hurdles for the dominant forces in society to sublate rather than a pique to a new mode of existence. Planetary multiplicity, that the fundamental atmospheric conditions of the Earth may become new, pushes but does not break the accumulated power of the plantation system, fostering new articulations of cheap labour and cheap land in a radically different climatic context. A sober look at the history of racial violence suggests that even the apocalypse will not offer a clean break. Aspects of the old will come to haunt the new; the altered ground under our feet is still marked by the history of the plantation.

\section{Endurance and escape}

The scepticism about the apocalypse in the African American tradition might, at first glance, suggest a pessimistic disposition. It seems that the end of the world is an ineffectual figure in debates on climate change, neither disclosing anything new nor fostering fundamental societal change. Furthermore, in claiming that apocalypse is part of the normal order of things, a form of climate fatalism sneaks into the African American tradition. The cycling movement of catastrophes beginning with the Middle Passage suggests that there is nothing to be done to deflect or divert the arrival of new biophysical conditions hostile to human existence. The social death that Orlando Patterson (1982) pinpoints at the core of the condition of the existence of the enslaved, and which has provided the linchpin of Afropessimism (Sharpe, 2016), has an affinity with the relentless return of apocalypses, climatic and otherwise.

Yet, such a claim is, we argue, too hasty. Climate fatalism is undercut in Black accounts of the end of the world. The African American perspective highlights the pervasiveness of apocalypse but pulls back from asserting its inescapability; hope vies with pessimism. What sort of hope, however, is elaborated in Black environmental thought? One of the most common forms of hope in environmental thinking more generally is that it is possible to defer the apocalypse, doing everything in the present to push the catastrophic collapse of the current social order onto the distant horizon. So, Carl Cassegård and Håkan Thörn (2018, p. 562) suggest that the dominant tenor of the contemporary environmental movement is 'future-oriented pessimism'. By raising fears about the coming catastrophe, it is hoped that governments and peoples will take action in the present to prevent future disaster (Arias-Maldonado, 2021).

Yet, the idea of deferring the apocalypse sits uncomfortably in the African American tradition; the Benjaminian notion of halting catastrophe in its tracks runs up against a challenge. The cyclical nature of apocalypse - that the plantation system makes one wasteland after another, that the end of the world (whether in the social struggles of the 
past or the meteorological shifts of the future) fails to bring liberation - suggests that the emergency brakes may not be sufficient to the problem at hand. While the apocalypse may not be desirable, it is also something that cannot be cancelled. So, on the Black perspective traced here, the apocalypse is not to be hastened as a means of advancing to utopia, fatalistically accepted as unavoidable, or deferred endlessly through action in the present. These options do not, however, exhaust possible dispositions to the end of the world. In the African American theoretical and cultural tradition, there are attempts to approach the apocalypse in terms of endurance and escape. There is a need to, on the one hand, weather the hostility of the current social order to Black life and, on the other, stake out a path of development that is partially autonomous from the cycle of apocalyptic endings.

More specifically, a form of maroon survivalism has been articulated, in which the task is to build communities that offer a shelter from the apocalyptic processes unleashed by the Middle Passage. The term survivalism might, at first glance, evoke phenomena like the prepper movement, which aims to endure the apocalypse by building bunkers and stockpiling food (O'Connell, 2019). However, whereas preppers conceive of the apocalypse in terms of competitive individualism and masculine prowess, a radically different form of survivalism is developed by maroons. Escaped enslaved people across the Black Atlantic world formed relatively autonomous 'zones of refuge', areas outside the reach of the destructive plantation system (Scott, 2009, p. 133). In Sylvia Wynter's (n.d., p. 73; emphasis in original) terms, marronage is a 'dialectical response to the capitalist plantation system', involving both the refusal of Black people's status as merchandise and the creation of a society in which they could rehumanise themselves (see also Roberts, 2015). Marronage is about living through the apocalypse, with escaped slave communities hiding themselves from hostile outsiders, plotting defence strategies and meeting their basic needs. However, maroon communities were also oriented towards a break with the dominant contours of the plantation, offering a foretaste of an alternative mode of living that eschews backbreaking labour, environmental devastation and racial violence.

Maroon survivalism is not confined to the communities of escaped slaves formed prior to processes of formal abolition. It is a disposition that has deep roots in the African American tradition. As Greg Thomas (2016, p. 72) emphasises, marronage is a 'resistance science' that animates everything from music to protests, festivals to subjectivity. In particular, the entwinement of existence and transformation has been taken up by African American writers specifically concerned with the climate catastrophe. Octavia Butler's novels Parable of the Sower (1993) and Parable of the Talents (1998), which follow a young Black woman attempting to found a new religion in a future California riven by political collapse and environmental turbulence, are particularly instructive in this regard. Lauren Oya Olamina, the protagonist of the novels, is clear that part of the purpose of her new religion, called Earthseed, is to endure the cycle of catastrophes: 'From what I've read [...] the world goes crazy every three or four decades. The trick is to survive until it goes sane again' (Butler, 1993, p. 229). The key teaching of Earthseed, that God is Change, reinforces this desire to adapt to shifting circumstances. The change that has occurred requires a response, a new mode of living attuned to the distinctive climatic contours of an alternative world. Lauren and her followers abandon their homes 
in drought-stricken southern California and found a new community, called Acorn, in the north of the state. In Donna Haraway's (2016, p. 120) words, Acorn is a place of 'wounded flourishing', its residents achieving a fragile form of freedom that is stalked but not overwhelmed by the catastrophes beyond its walls. Like the maroons who cemented their bond to one another by 'kissing the earth', Acorn works with the grain of the environment to produce a new form of sociality (Wynter, n.d., p. 77; see also Malm, 2018).

However, as an articulation of maroon survivalism, Earthseed goes beyond endurance. The task is to harness the changeableness of the world to effect a fundamental break with the cycle of apocalyptic collapses. For Lauren, like Delany and Du Bois, this involves looking outwards beyond the confines of the Earth: 'The Destiny of Earthseed is to take root among the stars' (Butler, 1998, p. 75). The utopian horizon of Earthseed is to found a new community in outer space, establishing an alternative social order that is emancipated from the degraded contours of the Earth. Butler articulates a desire to disentangle the fate of humanity from the corrupt social and climatic conditions of its home planet, positing a sideways movement beyond the repetition of disasters and recursive breakdown. The climate apocalypse does not, then, reveal something unknown or trigger a transformative process. It does, however, offer a repeated impetus to chart a new historical trajectory, fostering a form of maroon survivalism predicated on the coming together of persistence and flight. The apocalypse may have to be endured in the future, the catastrophes on the horizon suggesting that survival is once again at stake, but this is not the eternal or inevitable condition of humanity. There are pathways beyond the cycle of apocalyptic endings, 'alternative human sensibilities, solidarities and forms of flourishing' outside the coming together of cheap land and cheap labour that has overtaken the Earth (Stevenson, 2021, p. 223).

The act of disjoining the telos of humanity from the apocalyptic logics that currently envelop it is captured by two images. The first is from Space is the Place (1974), the classic Afrofuturist film written by and starring jazz musician Sun Ra. The film features Sun Ra arriving on Earth from Saturn, where he encourages African Americans to board his spaceship. In the final scene, just as Sun Ra's ship leaves the atmosphere to the chant of 'another world, another world', the Earth explodes. Space is the Place posits the ultimate act of marronage, where apocalyptic events on Earth are rendered unimportant by the charting of a new route in the stars. The second is the cover art of Public Enemy's album Fear of a Black Planet (1990), which features a black coloured planet eclipsing the blue marble image of the Earth. The cover pastiches the classic science fiction film Star Wars (1977), with the black planet closely recalling the Death Star and the album's name written in the style of the film's renowned opening crawl. In this way, Public Enemy's album playfully recalls the dreams of the space age while also imbuing them with a utopian content. Fear of a Black Planet suggests that, while the emergence of a planet for African Americans may be apocalyptic from the perspective of white supremacy, the eclipse of the Earth represents a form of freedom for Public Enemy, positing the possibility of a world independent of the degraded contours of the old planet. 


\section{Conclusion: Marronage as metaphor}

It would be wrong to treat dreams of escaping into outer space as innocent. Space colonisation, as the name suggests, bears the marks of terrestrial colonisation. Whether it be the representation of other planets as a terra nullius or plans to ruthlessly extract minerals from asteroids, there are clear affinities between the two processes (Bawaka Country, 2020). This is hinted at by Butler. At the close of The Parable of the Talents, the spaceship launched from Earth bears the name Christopher Columbus, suggesting that the history of chattel slavery and settler colonialism that began in 1492 is poised to repeat itself. Other Black science fiction writers have explored the ambiguities of space travel in more detail. For instance, Nalo Hopkinson's Midnight Robber (2000) imagines that the arrival of the peoples of the Caribbean on a new planet reprises processes of slavery and colonialism. Rather than liberation, the escape to space inaugurates a new round of resistance. The novel is punctuated by moments of cooperation between the newly arrived Black population and displaced Indigenous groups, thus retooling the fragile 'Maroon-Amerindian fusions' of Caribbean history in a science fictional setting (Dillon, 2007, p. 29; see also King, 2016).

The maroon imaginaries of Butler, Sun Ra and Public Enemy, then, do not escape from the repetitive logic of the climate apocalypse. The cycle of catastrophes that begins with the ravaged land and destroyed bodies of the plantation intrudes into narratives of Black survival and flight, acting as a reminder of the pervasiveness of apocalyptic breakdowns. Yet, care should be taken here; there remains a kernel of value in these dreams of interstellar travel. To quote Thomas (2016, p. 71; emphasis in original), mountains are 'a powerful metaphor for all marronage' but this metaphor should not be 'literalized'; the political task is not to recreate the flight into the hills. Something similar can be said about space travel. Afrofuturist dreams of leaving the Earth retain value as a metaphor for the lateral shift beyond the continuum of events stretching from the plantation wasteland of the past to the ravaged world of the future. A figure of escape is required to look beyond the congealed contours of environmental destruction and racial oppression. Of course, other metaphors are possible, like Rivers Solomon's account of an underwater maroon nation formed by enslaved African women thrown overboard in the times of the Middle Passage in The Deep (2019). Both space and the sea are placeholders for a form of existence that cannot yet be described in positive and detailed terms, gesturing towards a utopia of fulfilment and liberation that currently sits just over the horizon.

Like Mann and Wainwright's (2018, p. 173) apophatic figure of 'Climate X', which can be glimpsed but not grasped in the current moment, maroon survivalism is a way of living beyond the apocalypse that is still searching for a concrete form. As such, it provides a guard, however weak and fragile, against the identification of the future with the continuation and generalisation of the plantation wastelands witnessed in the nineteenth century. The Black cultural and theoretical tradition thus looks in two directions at once. Certainly, the end of the world is insistent and immanent; it has happened before and threatens to happen again. The apocalypse is a means of articulating the catastrophes of the past and future, positing them as part of a cycling movement of breakdowns from which escape has not yet occurred. At the same time, the flights of the maroons from the 
capitalist plantation system provide a lesson for the future. All the time that openings for sideways movements remain, whether evoked by leaps into the cosmos or dives into the ocean, the apocalypse may be weathered and liberation achieved.

\section{Acknowledgements}

The authors would like to thank the journal's anonymous reviewers for their instructive and insightful comments on an earlier draft of this article.

\section{Declaration of conflicting interests}

The author(s) declared no potential conflicts of interest with respect to the research, authorship, and/or publication of this article.

\section{Funding}

The author(s) received no financial support for the research, authorship, and/or publication of this article.

\section{ORCID ID}

Joe P. L. Davidson (D) https://orcid.org/0000-0003-1800-3771

\section{References}

Arias-Maldonado, M. (2021). Reformulating emancipation in the Anthropocene: From didactic apocalypse to planetary subjectivities. European Journal of Social Theory. Epub ahead of print.

Baker, H. A. (1990). Long Black song: Essays in black American literature and culture. University of Virginia Press.

Ball, C. (1837). Slavery in the United States. John S. Taylor.

Bawaka Country. (2020). Dukarr lakarama: Listening to Guwak, talking back to space colonization. Political Geography, 81, 1-10.

Bennett, J. (2020). Being property once myself: Blackness and the end of man. Harvard University Press.

Brand, U., \& Wissen, M. (2021). The imperial mode of living: Everyday life and the ecological crisis of capitalism. Verso.

Browne, P. L. (2018). Reification and passivity in the face of climate change. European Journal of Social Theory, 21(4): 435-452.

Butler, O. (1993). Parable of the sower. Warner Books.

Butler, O. (1998). Parable of the talents. Seven Stories Press.

Cabral, A. (1988). Estudos Agrários de Amílcar Cabral. Instituto de Investigação Científica Tropical, Instituto Nacional de Estudos e Pesquisa.

Carney, J. A. (2021). Subsistence in the Plantationocene: Dooryard gardens, agrobiodiversity, and the subaltern economies of slavery. Journal of Peasant Studies, 48(5), 1075-1099.

Carson, R. (1962). Silent spring. Houghton Miffin.

Cassegård, C., \& Thörn, H. (2018). Toward a postapocalyptic environmentalism? Environment and Planning E: Nature and Space, 1(4), 561-578.

César, F. (2018). Meteorisations: Reading Amílcar Cabral's agronomy of liberation. Third Text, 32(2-3), 254-272.

Christian, B. (1987). The race for theory. Cultural Critique, 6, 51-63. 
Claborn, J. (2014). W. E. B. Du Bois at the Grand Canyon. In G. Garrard (Ed.), The Oxford Handbook of ecocriticism (pp. 118-131). Oxford University Press.

Clark, N., \& Szerszynski, B. (2021). Planetary social thought. The Anthropocene challenge to the social sciences. Polity.

Coates, T.-N. (2015). Between the world and me. Spiegel \& Grau.

Coates, T.-N. (2019). The water dancer. One World.

Colebrook, C. (2012). Not symbiosis, not now: Why anthropogenic change is not really human. The Oxford Literary Review, 34(2), 185-209.

Collins, P. H. (2002). Black feminist thought. Routledge.

Danowski, D., \& Viveiros de Castro, E. (2016). The ends of the world. Polity.

Davis, J., Moulton, A. A., Van Sant, L., \& Williams, B. (2019). Anthropocene, Capitalocene, ... Plantationocene? Geography Compass, 13(5), 1-15.

Delany, M. ([1859] 2003). Comets. In R. S. Levine (Ed.) Martin R. Delany: A documentary reader (pp. 313-314). University of North Carolina Press.

Dillon, Grace L. (2007). Indigenous scientific literacies in Nalo Hopkinson's ceremonial worlds. Journal of the Fantastic in the Arts, 18(1), 23-41.

Douglass, F. (1855). My bondage and my freedom. Miller, Orton \& Mulligan.

Du Bois, W. E. B. (1920). Darkwater: Voices from within the veil. Harcourt.

Ellis, C. (2014). Amoral abolitionism: Frederick Douglass and the environmental case against slavery. American Literature, 86(2), 275-303.

Ford, J. E. (2018). When disaster strikes: On the apocalyptic tone of hip hop. ASAP/Journal, 3(3): $595-622$.

Foster, J. B. (2020). Why ecological revolution? In L. King \& D. M. Auriffeille (Eds.) Environmental sociology. Rowman \& Littlefield.

Foster, M. S. (1999). In the face of "Jim Crow": Prosperous blacks and vacations, travel and outdoor leisure, 1890-1945. The Journal of Negro History, 84(2), 130-149.

Frye, N. (1982). The great code: The Bible and literature. Harcourt Brace Jovanovich.

Gergen, M., Smith, S., \& Vasudevan, P. (2020). Earth beyond repair: Race and apocalypse in collective imagination. Environment and Planning D: Society and Space, 38(1), 91-110.

Glave, D. D. (2010). Rooted in the earth: Reclaiming the African American environmental heritage. Lawrence Hill Books.

Hall, J. R. (2009). Apocalypse: From antiquity to the empire of modernity. Polity.

Haraway, D. J. (2016). Staying with the trouble: Making kin in the Chthulucene. Duke University Press.

Harper, M. (2016). The end of days: African American religion and politics in the age of emancipation. University of North Carolina Press.

Hartman, S. (2007). Lose your mother: A journey along the Atlantic slave route. Farrar, Straus and Giroux.

Hopkinson, N. (2000). Midnight robber. Grand Central Publishing.

Hurley, J., \& Jemisin, N. K. (2018). An apocalypse is a relative thing: An interview with N. K. Jemisin. ASAP/Journal, 3(3), 467-477.

King, T. L. (2016). The Black shoals: Offshore formations of Black and native studies. Duke University Press.

Kulikoff, A. (2001). Tobacco and slaves. The development of southern cultures in the Chesapeake, 1680-1800. University of North Carolina Press. 
Latour, B. (2018). Down to earth: Politics in the new climatic regime. Polity.

Lothian, A. (2018). Old futures: Speculative fiction and queer possibility. New York University Press.

Malm, A. (2018). In wildness is the liberation of the world: On maroon ecology and partisan nature. Historical Materialism, 26(3), 3-37.

Malm, A. (2021). How to blow up a pipeline. Verso.

Mann, G., \& Wainwright, J. (2018). Climate leviathan: A political theory of our planetary future. Verso.

Marx, K. ([1867] 1976). Capital: A critique of political economy, volume one. Penguin.

Maudlin, E. S. (2018). Unredeemed land: An environmental history of civil war and emancipation in the cotton South. Oxford University Press.

McKibben, B. (2019). Falter: Has the human game begun to play itself out? Wildfire.

McNeish, W. (2017). From revelation to revolution: Apocalypticism in green politics. Environmental Politics, 26(6), 1035-1054.

Mirzoeff, N. (2018). It's not the Anthropocene, it's the white supremacy scene. In R. Grusin (Ed.), After extinction (pp. 123-150). University of Minnesota Press.

Mitchell, A., \& Chaudhury, A. (2020). Worlding beyond 'the' 'end' of 'the world': White apocalyptic visions and BIPOC futurisms. International Relations, 34(3), 309-332.

Montgomery, M. L. (1996). The apocalypse in African-American fiction. University Press of Florida.

Moore, J. W. (2015). Capitalism in the web of life. Verso.

O'Connell, M. (2019). Notes from an apocalypse. Granta.

Oliver, L. J. (2015). Apocalyptic and slow violence: The environmental vision of W. E. B. Du Bois's Darkwater. ISLE: Interdisciplinary Studies in Literature and Environment, 22(3): 466-484.

Patterson, O. (1982). Slavery and social death. Harvard University Press.

Read, R., \& Alexander, A. (2019). This civilization is finished. Simplicity Institute.

Roberts, N. (2015). Freedom as marronage. University of Chicago Press.

Ruffin, K. N. (2010). Black on earth: African American ecoliterary traditions. University of Georgia Press.

Rusert, B. (2013). Delany's comet: Fugitive science and the speculative imaginary of emancipation. American Quarterly, 65(4), 799-829.

Rushdy, A. (1999). Neo-slave narratives: Studies in the social logic of a literary form. Oxford University Press.

Scott, J. C. (2009). The art of not being governed. Yale University Press.

Scranton, R. (2015). Learning to die in the Anthropocene. City Lights.

Seamster, L., \& Ray, V. (2018). Against teleology in the study of race: Toward the abolition of the progress paradigm. Sociological Theory, 36(4): 315-342.

Sharpe, C. (2016). In the wake: On Blackness and being. Duke University Press.

Simon, Z. B. (2020). The limits of Anthropocene narratives. European Journal of Social Theory, 23(2):184-199.

Skrimshire, S. (2019). Activism for end times: Millenarian belief in an age of climate emergency. Political Theology, 20(6), 518-536.

Smith, K. K. (2007). African American environmental thought: Foundations. University Press of Kansas.

Solomon, R. (2019). The deep. Hodder. 
Stevenson, N. (2021). Critical theory in the Anthropocene: Marcuse, Marxism and ecology.

European Journal of Social Theory, 24(2): 211-226.

Stewart, G. R. (1941). Storm. Random House.

Stewart, M. A. (2006). Slavery and the origins of African American environmentalism. In D. D.

Glave \& M. Stoll (Eds.), To love the wind and the rain: African Americans and environmental history (pp. 9-20). University of Pittsburgh Press.

Swyngedouw, E. (2010). Apocalypse forever? Post-political populism and the spectre of climate change. Theory Culture \& Society, 27(2-3), 213-232.

Thomas, G. (2016). Marronnons / Let's Maroon. Small Axe, 49, 62-78.

Tsing, A. L. (2015). The mushroom at the end of the world. Princeton University Press.

Urry, J. (2011). Climate change and society. Polity.

Vergès, F. (2017). Racial Capitalocene. In G. T. Johnson \& A. Lubin (Eds.), Futures of Black radicalism (pp. 72-82). Verso.

Wallace-Wells, D. (2019). The uninhabitable earth. Penguin.

West, C. (2003). Philosophy and the Afro-American experience. In T. L. Lott \& J. P. Pittman (Eds.), A Companion to African-American Philosophy (pp. 7-32). London: Blackwell.

Woods, C. (1998). Development arrested: The blues and plantation power in the Mississippi Delta. Verso.

Wright, G. (1986). Old South, new South: Revolutions in the Southern economy since the civil war. Basic Books.

Wynter, S. (n.d.). "Black metamorphosis.” Unpublished manuscript.

Yusoff, K. (2018). A billion Black anthropocenes or none. University of Minnesota Press.

\section{Author biographies}

Joe P. L. Davidson is a PhD student in the Department of Sociology at the University of Cambridge. His dissertation focuses on the relationship between utopia and temporality. His work has been published in Current Sociology, The Sociological Review and Theory, Culture \& Society.

Filipe Carreira da Silva is a Senior Research Fellow at the Institute of the Social Sciences of the University of Lisbon and a Fellow of Selwyn College, University of Cambridge. He specializes in social theory. He is the author of Mead and Modernity (2008) and the co-author (with Mónica Brito Vieira) of The Politics of the Book (2019). 